\title{
Diauxic and Antimicrobial Growth Phases of Streptomyces Tenjimariensis: Metabolite Profiling and Gene Expression
}

\author{
Judith R. Denery¹, Michael J. Cooney² and Qing X. Li ${ }^{1 *}$
}

${ }^{1}$ Department of Molecular Biosciences and Bioengineering, University of Hawaii at Manoa, Honolulu, HI96822, USA

${ }^{2}$ Hawaii Natural Energy Institute, University of Hawaii at Manoa, Honolulu, HI 96822, USA

\begin{abstract}
This work reports the use of metabolic profiling and PCR techniques as a means of studying the growth of Streptomyces tenjimariensis. Metabolic profiles were created from gas chromatography-mass spectrometry analysis of extracts prepared through extraction of the intracellular contents followed by fractionation of the polar metabolites and trimethylsilyl derivatization. All chromatograms yielded profiles of between 100 and 200 metabolites. The major metabolite groups including organic acids, amino acids, sugars, sugar alcohols, and phosphatidyl sugar alcohols were identified and their profiles correlated to growth stage and antimicrobial activity. Statistical analysis including analysis of variance, hierarchical cluster analysis, and principal component analysis suggested that differences between the major growth phases could be distinguished, and may be used to establish patterns amongst key metabolites. The expression of four enzyme genes involving substrate utilization and istamycin biosynthesis was detected with reverse transcriptase-PCR across four time points during the growth of $S$. tenjimariensis.
\end{abstract}

Keywords: Metabolic profiling; Streptomyces tenjimariensis istamycin

\section{Introduction}

Although analysis of select compounds and metabolites has been used extensively to elucidate specific metabolic pathways, it is now more widely being applied to cataloguing all (or most of) the biochemicals associated with an organism's metabolism (or metabolome) [1]. Metabolic profiling parallels techniques measuring changes in gene expression such as 2-D gel [2] and mass spectrometric protein profiling [3], serial analysis of gene expression [4], and cDNA microarray analysis [5]. Both the metabolic and gene expression approaches address the phenotypic plasticity of a particular organism but from different perspectives. Differential gene expression identifies the genes expressed in response to specific environmental cues or stresses, while metabolic profiling measures the metabolites. When combined, however, these techniques promise a powerful means of assigning functions to previously uncharacterized genes, as in the field of functional genomics [6,7], or toward understanding the coordinated processes of whole organisms as is the goal of systems biology $[8,9]$.

Of specific commercial interest is the potential that metabolite profiling holds for the fields of pharmaceutical discovery, clinical diagnostics, medical treatment, and bioprocess optimization. As with established gene expression technologies, it is assumed that when metabolite profiles are compared across stages of growth,variations in metabolites produced in response to specific environmental cues and stresses can be identified.Such an approach has numerous industrial applications including narrowing a list of target compounds, identifying disease biomarkers, optimizing growth conditions, or verifying product quality.

While a truly comprehensive analysis of the full complement of the metabolites within an organism remains technologically elusive [10], many of the current techniques can quantitatively measure, in a single measurement, a large number of compounds within a number of important metabolic classes $[11,12]$. For this task, gas chromatographymass spectrometry (GC-MS) is particularly well suited. GC after chemical derivatization allows for the separation of a wide range of compounds with polar functionalities.Peaks can be identified based on reproducible mass fragmentation patterns and GC retention times.
While GC-MS has been used widely in plant metabolomics [12-14], human urine samples [15,16], and yeast $[17,18]$, it has only just begun to be adopted for the metabolite profiling of a few model microbial systems $[19,20]$.

To better understand the potential of metabolic profiling as a tool in determining metabolic differences between microbial growth phases, we have profiled the major metabolites of Streptomyces tenjimariensis grown in batch bioreactor culture. S. tenjimariensis, an actinomycete initially isolated from sea mud samples in Sagami Bay, Japan [21], is known to produce a group of antibiotics: the istamycins, displaying potent antimicrobial activities against many Gram-negative and Gram-positive bacteria [22]. Previous work with S.tenjimariensis has shown antibiotic production which can be induced through coculturing with other marine species [23], however, little has been done in characterizing cell metabolism or biosynthesis of the antibiotics and genes or gene expression in S. tenjimariensis [24].

Classified as aminoglycoside antibiotics, the istamycins are characterized as di-pseudosaccharides containing a 1,4-diaminocyclitol structure.This group of antibiotics is known to be produced by four genera [24]. Studies with blocked pathway mutants identifying some of the genes coding for the antibiotic biosynthesis pathways in other species [24] may provide some indication of the biosynthetic route for istamycin, however, no studies have been done to determine the mode of antibiotic biosynthesis in S. tenjimariensis.

Previous studies have shown two possible routes for biosynthesis

${ }^{*}$ Corresponding author: Qing X. Li, Department of Molecular Biosciences and Bioengineering, University of Hawaii at Manoa, Honolulu,HI96822, USA, Tel: +1 808-956-2011; Fax: +1-808-956-3542; E-mail: qingl@hawaii.edu

Received March 25, 2011; Accepted July 14, 2011; Published July 28, 2011

Citation: Denery JR, Cooney MJ, Li QX (2011) Diauxic and Antimicrobial Growth Phases of Streptomyces Tenjimariensis: Metabolite Profiling and Gene Expression. J Bioengineer \& Biomedical Sci 1:101. doi:10.4172/2155-9538.1000101

Copyright: (c) 2011 Denery JR, et al. This is an open-access article distributed under the terms of the Creative Commons Attribution License, which permits unrestricted use, distribution, and reproduction in any medium, provided the original author and source are credited. 
of aminoglycoside antibiotics. In Micromonospora olivasterospora the precursor compound myo-inositol is oxidized and aminated to form scyllo-inosamine that is then linked to D-glucosamine to produce a double saccharide ring structure [24]. As a part of the biosynthetic pathway for streptomycin [24], the enzyme myo-inositol dehydrogenase (MYO) is responsible for the first step of the two step conversion of myo-inositol into scyllo-inosamine. However, other studies have found that the most common enzyme for aminoglycoside biosynthesis is L-glutamine: aminocyclitol aminotransferase that is responsible for the conversion of 2-deoxy-scyllo-inosose into 2-deoxyscyllo inosamine [24]. In Streptomyces tenebrarius, the genes for the L-glutamine 2-deoxy-scyllo-inosose aminotransferase (AMT) and for 2-deoxy-scyllo-inosose synthase (DOI) involved with the first step of aminoglycoside antibiotic biosynthesis have been characterized [24].

This work reports the use of metabolic profiling as a means of distinguishing between the growth phases of S. tenjimariensis and gene expression of the enzymes AMT, DOI and MYO involved in the biosynthesis of aminoglycoside antibiotics. The diauxic growth pattern observed by metabolic profiling indicated the induced expression of an extra-cellular $\alpha$-amylase (AMY) once glucose has been depleted. Therefore, gene expression of AMY was also detected with PCR.

\section{Materials and Methods}

\section{Cell maintenance and preparation of inoculums}

Streptomyces tenjimariensis SS-939 was obtained from American Type Culture Collection (ATTC 31603).

Prior to each cultivation, the original vial glycerol stocks from the master seed bank were thawed and suspended in (1:5 dilution) sterile complex medium (potato starch, $20 \mathrm{~g} \mathrm{~L}^{-1}$, soybean meal $20 \mathrm{~g} \mathrm{~L}^{-1}, \mathrm{NaCl} 2$ $\mathrm{g} \mathrm{L}^{-1}$ ). The solution was plated onto inorganic salts starch agar (ISP No. 4) and then incubated at $28^{\circ} \mathrm{C}$ until colony formation was observed. After incubation, individual colonies were selected, inoculated into shake flasks containing complex media, and grown for 5 days. From this culture, aliquots $(20 \mathrm{x}, 1 \mathrm{~mL})$ were added to glycerol $(20 \%)$ and frozen $\left(-80^{\circ} \mathrm{C}\right)$ to sustain genetic stability [25]. Reactor inocula were prepared by placing spores from an individual colony into $75 \mathrm{~mL}$ of the prepared soybean meal starch medium in a $250-\mathrm{mL}$ baffled flask and incubated at $28^{\circ} \mathrm{C}$ and $180 \mathrm{rpm}$ [25].

"Hottas"medium (2 L) comprised of $1 \%$ starch, $1 \%$ soy meal, $0.2 \%$ glucose, $0.3 \% \mathrm{NaCl}, 0.1 \% \mathrm{MgSO} 4,0.1 \% \mathrm{~K}_{2} \mathrm{PO}_{4}$ [26] was autoclaved, centrifuged at 10,000 relative centrifugal force (RCF) for $10 \mathrm{~min}$ at $4{ }^{\circ} \mathrm{C}$ to remove insoluble ingredients in the soy meal, and autoclaved again.

\section{Bioreactor growth and sampling}

All bioreactor experiments were done in a 2-L jacketed vessel with an integrated control system (micro-DCU, B. Braun Biotech., Germany) that maintained $28^{\circ} \mathrm{C}$, agitation at $750 \mathrm{rpm}$, and aeration at $0.5 \mathrm{~L} \mathrm{~min}^{-1}$. Inlet air was sterilized by filtration $(0.2 \mu \mathrm{m})$ and the outlet gas stream bubbled through ethanol (75\%). The $\mathrm{pH}$ was adjusted to neutral automatically by addition of $4 \mathrm{M} \mathrm{NaOH}$ or $1 \mathrm{M} \mathrm{HCl}$.

The bioreactor and medium were autoclaved separately. The bioreactor was sterilized at $121^{\circ} \mathrm{C}$ for $20 \mathrm{~min}$ while the medium was autoclaved in $1.5 \mathrm{~L}$ volumes for $30 \mathrm{~min}$ at $121^{\circ} \mathrm{C}$. Once autoclaved, the bioreactor was allowed to cool under a positive pressure flow of sterile air. Once cooled, the sterilized medium was transferred to the bioreactor using positive pressure of sterile air to force the media into the bioreactor. Thereafter, the bioreactor was inoculated with $75 \mathrm{~mL}$ $(5 \% \mathrm{v} / \mathrm{v})$ of $S$. tenjimariensis inoculum previously grown in shake flask culture for $48 \mathrm{~h}$ in Hotta's media.

Culture samples $(30-35 \mathrm{~mL})$ were sterilely withdrawn at specific time points and divided into aliquots for dry cell weight $(\mathrm{dcw})$ determination $(9-15 \mathrm{~mL})$, metabolite profiling $(10 \mathrm{~mL})$, nucleic acid archives $(5 \mathrm{~mL})$, antimicrobial assays $(0.5 \mathrm{~mL})$, supernatant analysis $(0.5 \mathrm{~mL})$, microscopic observation $(\sim 20 \mu \mathrm{L})$ and plating $(50 \mu \mathrm{L})$ on inorganic salts agar for assurance of culture purity. To ensure samples accurately reflected culture growth, the sample tube was purged with culture broth prior to each sample. The total volume of all samples combined was less than one tenth of the original culture volume.

\section{Metabolic quenching}

The two 5-mL aliquots to be used for later metabolite profiling studies were immediately quenched in duplicate glass vials,each containing $25 \mathrm{~mL}$ neat methanol $\left(-80^{\circ} \mathrm{C}\right)$ in order to obtain a final 1:5 ratio of culture sample: cold methanol. Through immediate quenching of the bioreactor samples in $-80^{\circ} \mathrm{C}$ methanol, instantaneous cessation of metabolic activity is assumed. In previous studies, mixtures of cold methanol and buffers have been used for metabolite quenching [2729], however, in an initial comparison of the mass spectral output using various buffer salts we found significant interference with the quality of the GC-MS signal.Therefore, the cold unmodified methanol was used with the careful control of temperature and minimization of handling time maintained consistently across all sampling times.

\section{Dry cell weight determination}

Dry cell weight was determined in triplicate by filtering aliquots of cell culture ( $5 \mathrm{~mL}$ in early growth phases, $3 \mathrm{~mL}$ in later phases) over a $0.45 \mu \mathrm{m}$ nylon membrane (Whatman, Clifton, NJ, USA) followed by rinsing with deionized water at a volume $3 \mathrm{x}$ that of the sample. Before and after filtration, each membrane was rinsed with deionized water, heated in a microwave under low power for $20 \mathrm{~min}$, allowed to cool in a dessicator, and was weighed. Dry cell weight was taken as the difference between the before and after membrane weights. Relative cell mass was calculated for each sample as a percentage of $\mathrm{dcw}$ from the largest dcw value for each bioreactor run.

\section{Measurement of antimicrobial activity}

Antimicrobial activity was quantified using a well-diffusion assay with methicillin-susceptible Staphylococus aureus as the test strain [25]. Aliquots $(100 \mu \mathrm{L})$ of growing $S$. aureus cultures were added to autoclaved tryptic soy agar $(0.8 \%)$ just before solidification. Aliquots $(50 \mu \mathrm{L})$ of supernatants to be tested were dispensed into circular wells $\left(10 \mathrm{~mm}\right.$ diameter) and incubated at $37^{\circ} \mathrm{C}$ for $24 \mathrm{~h}$. Kanamycin (Sigma, St. Louis, MO, USA) standard was serially diluted $\left(7.5-750 \mu \mathrm{g} \mathrm{mL}^{-1}\right)$ and applied as an internal standard to each plate. Circular clearing zones indicated inhibition against $S$. aureus growth and the antimicrobial activity was measured with clearing zone diameters. S. aureus was kindly provided by the Department of Microbiology at the University of Hawaii at Manoa.

\section{HPLC analysis of supernatant}

Each $0.5-\mathrm{mL}$ supernatant sample was filtered through a $0.2-\mathrm{mm}$ sterile nylon Econofilter (Agilent Technologies, Palo Alto, USA) and analyzed on an Agilent 1100 HPLC equipped with an autosampler and a refractive index detector. Samples were analyzed with a Supelcogel $\mathrm{C}-610 \mathrm{H}$ ion exchange column (Supelco, Bellefonte, USA) maintained at $30^{\circ} \mathrm{C}$ with a column thermostat (Timberline, Boulder, USA) at a flow of $0.5 \mathrm{~mL} \mathrm{~min}^{-1}$ with $0.1 \%$ sulfuric acid as mobile phase. Each run lasted $15 \mathrm{~min}$. Retention times of metabolites were compared with those of 
authentic standards $\left(20 \mathrm{mg} \mathrm{mL}^{-1}\right)$ in magnesium sulfate solutions (5 mg $\left.\mathrm{mL}^{-1}\right)$.

\section{Metabolite extraction and analysis}

Quenched metabolite samples were stored on dry ice and then centrifuged at $10,000 \mathrm{RCF}$ and $-20^{\circ} \mathrm{C}$ for $10 \mathrm{~min}$. The supernatant was removed and stored at $-20^{\circ} \mathrm{C}$. The cell pellet was re-suspended to its original volume $(5 \mathrm{~mL})$ with methanol $\left(-20^{\circ} \mathrm{C}\right)$. The tubes were rinsed ( $3 \times 3 \mathrm{~mL}$ methanol) and the rinsates were added to the cell pellet suspension. This suspension was then transferred to fill $2 \mathrm{~mL}$ lysis tubes (Midwest Scientific, Valley Park, USA) containing $0.2 \mathrm{~mL}$ zirconium beads and stored on dry ice until lysis.

Cell lysis was executed on a FastPrep system (QBiogene, Montreal, Canada) with the samples stored on dry ice in between each of 3-15 s $\left(6 \mathrm{~m} \mathrm{~s}^{-1}\right)$ cycles. Samples were then centrifuged at 14,000 rpm for $3 \mathrm{~min}$ and the metabolite containing supernatants were pooled and brought to a final volume of $25 \mathrm{~mL}$.

Specific samples from the pooled lysate were normalized to equivalent $\mathrm{dcw}$ values between $1.00-2.56 \mathrm{~mL}$ (Table 1) and then placed into glass centrifuge tubes. Metabolites were extracted into separate aqueous methanol (polar) and chloroform (nonpolar) fractions [12]. A $50-\mu \mathrm{L}$ volume of ribitol $\left(2 \mathrm{mg} \mathrm{mL}^{-1}\right.$ in water) was added as an internal standard to each cell lysate sample and then vortexed with $1 \mathrm{~mL}$ of water before being placed in a water bath and agitated at $70^{\circ} \mathrm{C}$. The tubes were centrifuged at 12,000 rpm for $3 \mathrm{~min}$ and the supernatant was decanted into fresh glass tubes. To each extract $1 \mathrm{~mL}$ of chloroform was added and the tubes were vortexed and agitated at $37^{\circ} \mathrm{C}$ for $5 \mathrm{~min}$. The tubes were again centrifuged at 12,000 $\mathrm{rpm}$ for $3 \mathrm{~min}$ and the supernatant transferred to new glass tubes. The remaining non-polar phase was re-rinsed with $1 \mathrm{~mL}$ of a 1:1 water /methanol solution to remove any remaining polar sample and spun again at 12,000 rpm for $3 \mathrm{~min}$. This rinsed upper phase was combined with the previous polar supernatant and spun at 4,000 rpm for $10 \mathrm{~min}$. The upper phase polar extract was removed to fresh tubes and frozen at $-80^{\circ} \mathrm{C}$ followed by lyophilization overnight on a Freezone 6-1 lyophilizer (Labconco, Kansas City, USA) at $-40^{\circ} \mathrm{C}$ under a vacuum of less than $130 \mathrm{mBar}$.

The dried polar fraction was methoxylated for $90 \mathrm{~min}$ at $30^{\circ} \mathrm{C}$ with $50 \mu \mathrm{L}\left(20 \mathrm{mg} \mathrm{mL}^{-1}\right)$ methoxyamine hydrochloride(Sigma) in dry pyridine followed by silylation with $80 \mu \mathrm{L} \mathrm{N}$-methyl-N-trimethylsilyltrifluoroacetamide (MSTFA) (Sigma) for $120 \mathrm{~min}$ at ambient temperature to derivatize the acidic protons. Methoxylation with methoxyamine limited the cyclization of sugars [30] and protected $\alpha$-keto acids from decarboxylation [31].

\section{Gas Chromaography and Mass Spectrometry}

One- $\mu \mathrm{L}$ aliquots of derivatized extracts were immediately analyzed on a Varian 1200 gas chromatograph-mass spectrometer equipped with a $30 \mathrm{~m} \times 250 \mu \mathrm{m}$ FactorFour column VF- 5ms (Varian, Palo Alto, USA) [12]. Mass spectra were recorded from $m / z 50$ to 600 and compared with those in the National Institute for Standards and Technology (NIST) and trimethyl silyl (TMS) (Oliver Fiehn Group, Golm, Germany) mass spectral databases, and available in-house standard libraries.

\begin{tabular}{|c|c|c|c|}
\hline Sample & $\begin{array}{c}\mathrm{dcw}^{1} \\
\left(\mathrm{mg} \mathrm{ml}^{-1}\right)\end{array}$ & $\begin{array}{c}\text { Volume of lysate used } \\
\text { for extraction }(\mathrm{ml})\end{array}$ & $\begin{array}{c}\text { Amount of cells repre- } \\
\text { sented in cell lysate }(\mathrm{mg})\end{array}$ \\
\hline T24 & 1.80 & 2.56 & 4.6 \\
\hline T36 & 2.89 & 1.59 & 4.6 \\
\hline T60 & 4.60 & 1 & 4.6 \\
\hline
\end{tabular}

$1 \mathrm{dcw}=$ dry cell weight.

Table 1: Normalization of amounts of cell lysates for metabolite analysis.

\section{DNA isolation}

Cells were lysed through the addition of $120 \mu \mathrm{L}$ lysozyme solution (10 $\mathrm{mg} \mathrm{mL}^{-1}$ ) into $1.5 \mathrm{~mL}$ of bacterial culture, followed by incubation for $2 \mathrm{~h}$ at $37^{\circ} \mathrm{C}$. A Wizard Genomic DNA Purification Kit (Promega, Madison, WI, USA) was used to isolate DNA according to instructions for Gram-positive bacteria. DNA was eluted into $50 \mu \mathrm{L}$ sterile water.

\section{RNA extraction}

Samples $(2 \times 5 \mathrm{~mL})$ were collected at specific time points $(10$, 24,36 , and $60 \mathrm{~h}$ ) corresponding to early, mid, and late exponential growth, immediately quenched in RNA later (Ambion, Austin, TX, USA) solution in glass vials and archived at $-20^{\circ} \mathrm{C}$. RNA was extracted from the archived cells using the above-stated enzymatic lysis and the RNeasy extraction kit (Qiagen,Valencia,CA,USA). The volume used for extraction was dependent on each sample's dcw (Table 2). RNA samples were treated with 10 units of RNase-free DNase (Qiagen) to remove residual DNA. RNA was quantified using a NanoDrop (NanoDrop Technologies, Wilmington, DE, USA) spectrophotometer at $A_{260}$.

\section{Primer design for PCR}

Specific primers amplifying $\alpha$-amylase DNA were designed based on the published sequences found in other Streptomyces including: $S$. livadans (gene accession number Y13601), S. venezuelae (M25263), S. limosus (M18244), and S. coelicolor (AL939130). Specific primers amplifying MYO gene were based on published sequence for S. coelicolor (NP631049, NP631310) and S. avermitilis (NP828364, NP822409). Gene sequences were analyzed and aligned using Vector NTI bioinformatics software (Informax, Frederick, MD, USA). Based on conserved regions between sequences, primers were designed taking into account particular primer requirements: primers length between 14-30 bp, less than $5^{\circ} \mathrm{C}$ melting temperature difference between forward and reverse primers, limited GC repeats and secondary structure formation. The final design for targeting AMY consisted of a forward primer 5'-GTG TTG CGG AAR GCG ACC AT -3' and a reverse primer 5'-TAC GAG TTC ACC GAC CAC GAC G-3'. The final primers for MYO gene were 5'-CGS GAG GTS GKC GAG GTS T- 3' for the forward primer and 5'-ATC CAG CCC GCC TCC A-3' for the reverse. DOI and AMT primers were chosen based on primers designed for S. tenebrarius [32]. Primers used were: DOI-I: 5'-ACT CSG TSC TST CSC TSA AGC AGG CS-3', DOI-II: 5'-CGT GSC CSA CSG TGT GSC CGT ACT-3', AMT-I: 5'-TSG GSG CSG GSG ACG AGG TSA TC-3' and AMT-II: 5'-TGS GCC TGS GCG CAG TCC TCG AT-3'. The 16S rDNA primers were 5'- AGA GTT TGA TCM TGG CTC AG-3' and 5'- GGT TAC CTT GTT ACG ACT T-3' [33].

\section{Primer testing}

Initial primers were tested to determine their ability to amplify targeted genes through PCR. The PCR amplification conditions were one cycle of denaturation at $95^{\circ} \mathrm{C}$ for 4 min followed by 35 cycles of 15

\begin{tabular}{|c|c|c|l|l|l|}
\hline sample & $\begin{array}{l}\text { dcw }(\mathrm{mg} / \\
\mathrm{ml})\end{array}$ & $\begin{array}{l}\text { Volume of } \\
\text { cell sample } \\
\text { used for ex- } \\
\text { traction }(\mathrm{ml})\end{array}$ & $\begin{array}{l}\text { Concentra- } \\
\text { tion of RNA } \\
\text { product } \\
(\mathrm{ng} / \mu \mathrm{l})\end{array}$ & $\begin{array}{l}\text { Amount of } \\
\text { RNA used } \\
\text { for cDNA } \\
\text { synthesis } \\
(\mu \mathrm{l})\end{array}$ & $\begin{array}{l}\text { Calculated } \\
\text { amount of } \\
\text { synthesized } \\
\text { cDNA in 20 } \mu \mathrm{l} \\
\text { reaction }(\mathrm{ng} / \mathrm{\mu l})\end{array}$ \\
\hline $\mathrm{T} 10$ & 0.9 & 23 & 336.1 & 1.5 & 504 \\
\hline $\mathrm{T} 24$ & 1.80 & 11.5 & 704.4 & 0.7 & 493 \\
\hline $\mathrm{T} 36$ & 2.89 & 7.2 & 152.4 & 3.3 & 503 \\
\hline $\mathrm{T} 60$ & 4.60 & 4.5 & 37.7 & 13.3 & 501 \\
\hline
\end{tabular}

Table 2: Dry cell weight (dcw) and normalization of amounts of cells for RNA extraction and cDNA synthesis. 
$\mathrm{s}$ at $95^{\circ} \mathrm{C}$ for denaturation, $20 \mathrm{~s}$ at annealing temperature, and $32 \mathrm{~s}$ at $72^{\circ} \mathrm{C}$ for extension. A final extension for $7 \mathrm{~min}$ at $72^{\circ} \mathrm{C}$ completed the procedure. Where primers were obtained from the literature, suggested annealing temperature was used. When ideal annealing temperature was unknown, a temperature $2^{\circ} \mathrm{C}$ below primer $\mathrm{Tm}$ was initially attempted and then touchdown PCR composed of 40 cycles beginning at $68^{\circ} \mathrm{C}$ with a ramp rate of $-0.5^{\circ} \mathrm{C} /$ cycle down to $50^{\circ} \mathrm{C}$ was employed as a last resort. As suggested [34,35], 5\% dimethyl sulfoxide (SigmaAldrich) was added to the PCR reaction to aid in amplifying CG rich regions of template. Products meeting expected sizes were extracted and purified using an UltraClean GelSpin Kit (MoBio, Carlsbad, CA). Purified samples were sequenced at the Greenwood Molecular Biology Facility, University of Hawaii. Sequenced PCR products were compared to nucleotide sequences (Blastn) and proteins (Blastp) published in the National Library of Medicine's BLAST database. Products with high homology to Streptomyces or other related genera are assumed to verify that the designed primer sets can be used to identify the presence of the specific DNA of interest in S. tenjimariensis.

\section{Gene specific primer design for quantitative PCR}

The sequence data were used for the design of S. tenjimariensis species specific primers for the amplification of shorter DNA sequences as required for quantitative PCR (qPCR). These qPCR species specific primers consisted of an AMY forward primer 5'-GTC GGT GAA CTC GTA GCC -3' and a reverse primer 5'-CAA CCA CGA CAC CGA GCG3' (amplicon $130 \mathrm{bp})$. The MYO gene species specific primers were 5'GGC CGA GCT GTT CCT TGA AG-3' for the forward primer and 5'-ACA AGG CAG GCA TGG AAA CG-3' for the reverse (amplicon 90 bp). The DOI species specific primers were forward 5'-CAA GAA CTG CCT CGC CAT CC-3'and reverse 5'-GTG ACA CTG GTC TTG GCC TG-3'(amplicon $132 \mathrm{bp}$ ). The AMT species specific primers consisted of forward 5'-GGA GAC CGG CTG TAT GAC GCC G -3', and reverse 5'-CTT GAT CCC GGC TTC GTC CAC G-3' (amplicon 102 bp). The 16S rDNA species specific primers were forward 5'- GCG GCC TAT CAG CTT GTT GG-3' and reverse 5'- CCG TGT CTC AGT CCC AGT GT-3' (amplicon $97 \mathrm{bp}$ ). For the topoisomerase (TOPO) gene the qPCR species specific primers consisted of forward 5'-TTC GGA AGG TCG CGG ATG TG-3' and reverse 5' GTT GTC CCC GAC TAG CGA GA3'(amplicon $144 \mathrm{bp}$ ).

\section{RT-PCR}

RT-PCR was accomplished using an OneStep RT-PCR kit with the addition of an RNase Free DNase (Qiagen). Extracted mRNA $(\sim 20 \mathrm{ng})$ was used from each time point. Gene-specific primers for AMT, DOI, MYO, AMY, TOPO, and $16 \mathrm{~S}$ rDNA were used for separate reactions, testing target gene expression at each phase of $S$. tenjimariensis growth. The thermocycler was set for RT-PCR as follows: $30 \mathrm{~min}$ at $52^{\circ} \mathrm{C}$ for reverse transcription, $15 \mathrm{~min}$ at $95^{\circ} \mathrm{C}$ for the activation of Taq polymerase, followed by a 35 cycles starting with $30 \mathrm{~s}$ at $95^{\circ} \mathrm{C}$ for denaturation, $20 \mathrm{~s}$ at $54^{\circ} \mathrm{C}$ for annealing, and $1 \mathrm{~min}$ at $72^{\circ} \mathrm{C}$ for extension, and a final extension of $10 \mathrm{~min}$ at $72^{\circ} \mathrm{C}$. Control reactions, omitting the reverse transcription step, were run in parallel to ensure no DNA contamination. Negative controls were performed by adding sterile water in place of a nucleotide template. RT-PCR products were visualized through gel electrophoresis on a $2 \%$ agarose gel.

\section{cDNA synthesis}

cDNA was synthesized from purified RNA stocks using the iScript cDNA synthesis kit (BioRad, Hercules, CA, USA ), which the amount of RNA sample used was adjusted, so that each of the final cDNA products would be at approximately the same concentration $500 \pm 7 \mathrm{ng} / \mu \mathrm{L}$. All tubes were placed into a thermocycler (BioRad) for $5 \mathrm{~min}$ at $25^{\circ} \mathrm{C}, 30$ $\min$ at $42^{\circ} \mathrm{C}$, and $5 \mathrm{~min}$ at $55^{\circ} \mathrm{C}$. The final volume of product for each reaction was $20 \mu \mathrm{L}$.

\section{Quantitative PCR}

qPCR was performed at the Greenwood Molecular Biology Facility, using a BioRad iCycler and iQ SYBR Green Supermix. For each experimental set-up a standard curve was prepared with 6-10x serial dilutions of time $24 \mathrm{cDNA}$ products. For each of the cDNA standard and sample wells $1 \mu \mathrm{L}$ of cDNA was amplified in a $20-\mu \mathrm{L}$ reaction solution. The results were analyzed with the iCycler software. Calibration curves were analyzed and the efficiency values used for calculating the fold change for target and reference genes using the Pfaffl equation [36].

\section{Statistical analysis and bioinformatics}

Chromatographic peak areas were integrated and normalized to the internal standard. Representative metabolites analyzed were chosen from five categories: organic acids, amino acids, sugars, sugar alcohols, and phosphatidyl sugar alcohols. Log values of these 24 metabolites were averaged and compared between time points. Triplicate injections of each sample were analyzed and the results were averaged.

Metabolite profiles were analyzed using JMP 5.1 Statistical Software (SAS Institute, Cary, USA). ANOVA was used to examine the statistical difference in the quantities of the representative metabolites across the three time points.Using the hierarchical cluster analysis (HCA) platform, metabolite data were clustered into similar groups where values are statistically close together relative to other clusters. Cluster distances were computed based on standardized values using the Ward's minimum variance distance option. For principal component analysis (PCA), the principal components were derived from an eigenvalue decomposition of the correlation matrix. For each data combination, the first two principal components were plotted on an $x / y$ axis.

Metabolic information and pathway maps were obtained through queries made using KEGG (http://www.genome.jp/kegg/) [37] and Biocyc (http://biocyc.org) [38] pathway/genome databases. Cellular contextualization of metabolite data was made using the Pathway Tools Omics Viewer (http://biocyc.org) [39].

\section{Results and Discussion}

\section{Bioreactor growth and gross measures of metabolic change}

Figure 1 shows four metabolic stages as an initial rapid growth (RG1) phase, a transition phase of stalled growth (T), a secondary rapid growth phase (RG2) and a stationary (S) phase. The RG1 phase (0- 18 $\mathrm{h}$ ) is associated with exponential growth and production of biomass (doubling time $=9.4 \mathrm{~h}$ ) and a proportional consumption of base, thus identifying a metabolic phase in which glucose (confirmed by HPLC analysis of the supernatant- data not shown) was oxidized and an excess of acid excreted by the growing cells. Once the available glucose was fully consumed, growth temporarily halted, initiating a transition phase (T) that was identified by a period of stalled growth and a cessation of base consumption. Thereafter, exponential growth resumed (doubling time $=14.5 \mathrm{~h})$ during which time a secondary growth phase RG2 $(\sim 25-$ $48 \mathrm{~h}$ ) on available acids and starch was observed. Additionally, initial evidence of antimicrobial production coincided with the start of this phase and the shift from glucose catabolism to the utilization of starch, the primary remaining carbohydrate energy source available in the medium. Finally, a stationary phase $(\mathrm{S})$ was entered $(\sim 48 \mathrm{~h})$ at which 
time both acid consumption and growth slowed simultaneously.

\section{Metabolite profile and quantitation}

Figure 2 presents the metabolic profiles of the polar fractions extracted from each sample. Although each chromatogram yielded as many as 200 peaks, not all could be easily characterized or quantitatively analyzed. Several of the peaks were eliminated because they were identified as artifacts of the derivatization. Several remain considered as unknowns as they did not offer high identity matches with the NIST and TMS libraries or against mass fragmentation patterns of the in-house standard library. The others were excluded from the quantitation across time points if there was a zero value for its presence in any sample at any timepoint. Therefore, for the purpose of the present study, the quantitative analysis was focused on a subset of representative metabolites that showed clear fragmentation with high identity correlation to the compounds available in the MS libraries and that were present in all replicate samples at each timepoint.

The 24 metabolites chosen represent a broad array of intracellular metabolite classes with representatives from a number of metabolic pathways (Table 3 and Figure 3 for S. avermitilis intracellular mapping schematic). Statistical analysis of the representative metabolites showed average relative standard deviations (RSD) of $4.9 \%, 3.8 \%$, and $4.2 \%$ for the 24, 36 and $60 \mathrm{~h}$ time points, respectively. These values are consistent with other metabolite profiling studies that have shown analytical precision of $<5 \%$ RSD, much less than the estimate of biological variability $>30 \%$ RSD [40]. In general, the sugars showed the smallest $P$ values (Table 3 ) indicating high statistical significance for the decrease in sugar content within cells throughout the bioreactor run. A similar decreasing trend and statistical significance were observed for the sugar alcohols. However, a significant decline in several other primary metabolites was also found. The amino acids and organic acids varied significantly among the metabolites measured, obscuring any general trend.

\section{Multivariate analysis and visualization}

HCA and PCA were used to reduce data complexity and to help visualize profile specificities. Data were analyzed using HCA and PCA based on two different approaches. In the first approach, the culture metabolite data were organized based on the 24-metabolite values represented across the three measured time points of bioreactor growth. Using HCA, the metabolite data can be visualized as falling within three distinct clusters (Figure $4 \mathrm{a}$ ). Another representational view of the same metabolite data is illustrated with the PCA analysis plot (Figure

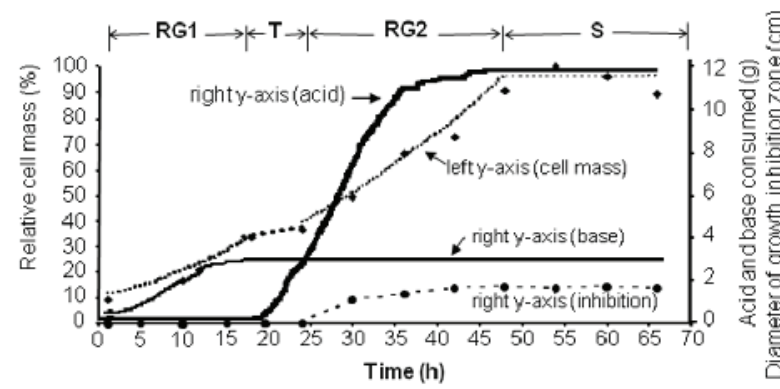

Figure 1: Growth curve of $S$. tenjimariensis in relation to acid and base consumption and bioactivity. Data are average values from two independent bioreactor experiments. Major stages of growth are marked as rapid growth 1 (RG1), transition (T), rapid growth 2 (RG2), and stationary (S). 4b) whereby two principal components were statistically determined from the entire data set and plotted in an $x / y$ bi-plot. The resultant PCA analysis supports the HCA clustering of the metabolites. Each cluster shows heterogeneity as far as which metabolite classes it includes. For example, the first cluster includes representative amino acids, sugars, sugar alcohols and organic acids. Such heterogeneity underscores the complexity of metabolite networks making it difficult to draw distinct conclusions regarding the behavior of compound classes. Since a metabolite may be represented within multiple pathways, it can be difficult to interpret the full metabolic consequence of concentration changes of the metabolite. This is consistent with the known dynamism of metabolic networks. Such metabolite groupings can, however, be used to visualize potential patterns in the behavior of metabolite groups relative to culture time and could serve as a basis for the determination of the function of unidentified compounds. In the second approach, the individual metabolite concentrations were analyzed as part of a profile representing each time point of bioreactor growth. In the HCA visualization (Figure 5a) it can be seen that the metabolite data self assorts into three distinct clusters representing times 24,36 and $60 \mathrm{~h}$. These clusters are similarly described using PCA analysis (Figure 5b) of the metabolite data from replicate profiles at each bioreactor time point. As can be seen, the time points distinctly self assort, indicating that the metabolite profiles (individually or as a group) are unique to each time point.

The growth of $S$. tenjimariensis lead to the observation of a diauxic growth pattern with two separate exponential growth stages, indicating that the bacterial culture underwent a distinct metabolic shift based on carbon substrate utilization. Since $S$. tenjimariensis was grown in a mixture of both glucose and starch as carbon sources, the initial rapid growth phase is evidence of the bacteria using glucose as its carbon source. However, once the available glucose is consumed, metabolic processes shift to degrade starch into simple sugars. The degradation of starch is accomplished through $\alpha$-amylase in a number of organisms.

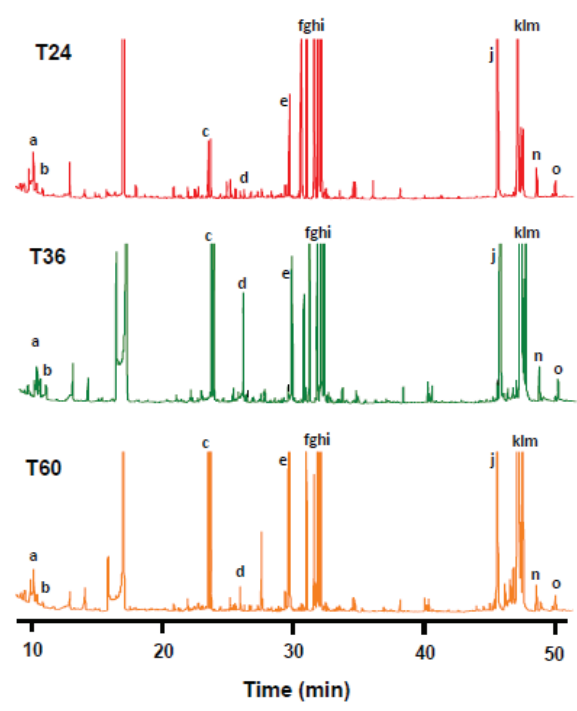

Figure 2: GC-MS chromatograms of metabolites in polar fractions of bioreactor samples at time 24, 36 and $60 \mathrm{~h}$. Letters indicate some of the metabolites for which MS spectra highly match those in NIST, TMS, and available standard in-house libraries. These are metabolites of a, lactate; b, glycolate; $c$, proline; d, glutamine; e, citrate; f, inositol; g, 3-deoxy hexonate; h, fructose; i, fructose; j, $\alpha$-glucopyranoside; k, trehalose; I, glucopyranose; m, maltose; n, a-galactopyranosiduroate; and o, glucose. 
Citation: Denery JR, Cooney MJ, Li QX (2011) Diauxic and Antimicrobial Growth Phases of Streptomyces Tenjimariensis: Metabolite Profiling and Gene Expression. J Bioengineer \& Biomedical Sci 1:101. doi:10.4172/2155-9538.1000101

Page 6 of 11

\begin{tabular}{|c|c|c|c|c|c|c|c|}
\hline \multirow[t]{2}{*}{ \# } & \multirow[t]{2}{*}{ Metabolite name } & \multirow[t]{2}{*}{ Class $^{1}$} & \multirow[t]{2}{*}{ Common Metabolic location } & \multicolumn{3}{|c|}{ Average relative content ${ }^{2} \pm$ standard deviation } & \multirow[t]{2}{*}{$p$ value } \\
\hline & & & & $24 \mathrm{~h}$ & $36 \mathrm{~h}$ & $60 \mathrm{~h}$ & \\
\hline 1 & Lactate & OA & glycolysis pyruvate, propanoate metabolism & $7.2 \pm 0.3$ & $7.2 \pm 0.3$ & $7.2 \pm 0.5$ & 0.0619 \\
\hline 2 & Glycolate & $\mathrm{OA}$ & glyoxylate, dicarboxylate metabolism & $7.1 \pm 0.1$ & $6.7 \pm 0.1$ & $6.3 \pm 0.1$ & 0.0005 \\
\hline 3 & 3-Hydroxy-propanoate & AA & beta-Alanine, propanoate metabolism & $6.8 \pm 0.2$ & $6.9 \pm 0.1$ & $6.7 \pm 0.2$ & 0.4917 \\
\hline 4 & Leucine & AA & $\begin{array}{l}\text { AA degradation/ synthesis } \\
A B C \text { transporters aminoacyl-tRNAsynthesis }\end{array}$ & $5.7 \pm 0.1$ & $5.0 \pm 0.1$ & $4.7 \pm 0.3$ & 0.0010 \\
\hline 5 & Malonate & OA & pyrimidine, beta-alanine metabolism & $6.4 \pm 0.3$ & $5.9 \pm 0.4$ & $5.4 \pm 0.3$ & 0.0274 \\
\hline 6 & Valine & AA & $\begin{array}{l}\text { AA degradation / synthesis } \\
\text { ABC transporters aminoacyl-tRNA biosynthesis propanoate } \\
\text { metabolism pantothenate and CoA synthesis }\end{array}$ & $5.3 \pm 0.3$ & $5.4 \pm 0.2$ & $5.1 \pm 0.3$ & 0.3959 \\
\hline 7 & Benzoate & $\mathrm{OA}$ & $\begin{array}{l}\text { phenylalanine metabolism benzoate, biphenyl degradation } \\
\text { alkaloid biosynthesis }\end{array}$ & $5.7 \pm 0.3$ & $5.5 \pm 0.2$ & $5.3 \pm 0.1$ & 0.1454 \\
\hline 8 & Succinate & $\mathrm{OA}$ & $\begin{array}{l}\text { TCA cycle } \\
\text { oxidative phosphorylation AA metabolism glyoxylate, dicarboxyl- } \\
\text { ate, propanoate, butanoate metabolism }\end{array}$ & $7.5 \pm 0.1$ & $6.4 \pm 0.2$ & $6.4 \pm 0.1$ & 0.0009 \\
\hline 9 & Dihydroxy-butanoate & OA & butanoate metabolism & $7.1 \pm 0.2$ & $6.7 \pm 0.1$ & $6.2 \pm 0.1$ & 0.0002 \\
\hline 10 & Erythrose & S & carbohydrate metabolism & $6.2 \pm 0.3$ & $6.3 \pm 0.1$ & $5.5 \pm 0.4$ & 0.0248 \\
\hline 11 & Proline & AA & $\begin{array}{l}\text { urea cycle } \\
\text { AA metabolism aminoacyl-tRNA synthesis } A B C \text { transporters }\end{array}$ & $6.7 \pm 0.1$ & $6.8 \pm 0.1$ & $6.3 \pm 0.3$ & 0.0491 \\
\hline 12 & Threonate & OA & ascorbate and aldarate & $6.4 \pm 0.2$ & $6.3 \pm 0.2$ & $6.3 \pm 0.3$ & 0.5087 \\
\hline 13 & Glycerol & SA & galactose, glycerolipid metabolism & $7.2 \pm 0.2$ & $6.8 \pm 0.1$ & $6.3 \pm 0.4$ & 0.0137 \\
\hline 14 & Glutamine & AA & purine, pyrimidine, glutamate, nitrogen metabolism & $7.6 \pm 0.7$ & $8.0 \pm 0.1$ & $7.5 \pm 0.3$ & 0.4411 \\
\hline 15 & Scyllo-inosose & S & inositol/ inositol phosphate metabolism & $6.3 \pm 0.6$ & $5.3 \pm 0.7$ & $5.7 \pm 0.4$ & 0.1310 \\
\hline 16 & Threonic acid & OA & $n / a^{3}$ & $6.4 \pm 0.1$ & $6.2 \pm 0.1$ & $6.1 \pm 0.2$ & 0.0576 \\
\hline 17 & Glycerol-3-phosphate & PSA & glycerolipid, glycerophospholipid metabolism ABC transporters & $6.9 \pm 0.1$ & $6.3 \pm 0.2$ & $6.5 \pm 0.5$ & 0.1878 \\
\hline 18 & Citrate & $\mathrm{OA}$ & $\begin{array}{l}\text { TCA cycle } \\
\text { AA, glycoxylate, dicarboxylate metabolism } \\
\text { reductive carboxylate cycle }\end{array}$ & $6.4 \pm 0.6$ & $5.9 \pm 0.4$ & $5.8 \pm 0.4$ & 0.3533 \\
\hline 19 & Inositol* & SA & $\begin{array}{l}\text { inositol, galactose, inositol phosphate metabolism phosphati- } \\
\text { dylinositol signaling system }\end{array}$ & $8.6 \pm 0.0$ & $8.3 \pm 0.1$ & $8.0 \pm 0.2$ & 0.0034 \\
\hline 20 & 3 Deoxy-hexonate & OA & $n / a^{3}$ & $7.9 \pm 0.1$ & $7.6 \pm 0.1$ & $7.3 \pm 0.2$ & 0.0032 \\
\hline 21 & Fructose* $^{*}$ & S & fructose, mannose, galactose, starch and sucrose metabolism & $8.2 \pm 0.0$ & $8.0 \pm 0.0$ & $7.7 \pm 0.1$ & 0.0005 \\
\hline 22 & Fructose & S & fructose, mannose, galactose, starch and sucrose metabolism & $8.1 \pm 0.0$ & $7.9 \pm 0.0$ & $7.6 \pm 0.3$ & 0.0004 \\
\hline 23 & Galactose & S & $\begin{array}{l}\text { galactose metabolism } \\
\text { ABC transporters bacterial chemotaxis }\end{array}$ & $6.5 \pm 0.1$ & $6.0 \pm 0.2$ & $5.6 \pm 0.3$ & 0.0109 \\
\hline 24 & Inositol† & SA & $\begin{array}{l}\text { inositol, galactose, inositol phosphate metabolism phosphati- } \\
\text { dylinositol signaling }\end{array}$ & $7.2 \pm 0.4$ & $6.9 \pm 0.2$ & $6.1 \pm 0.3$ & 0.0081 \\
\hline
\end{tabular}

${ }^{1} \mathrm{OA}=$ organic acid; $\mathrm{AA}=$ amino acid; $\mathrm{SA}=$ sugar alcohol; $\mathrm{S}=$ sugar; $\mathrm{PSA}=$ phosphatidyl sugar alcohol, ${ }^{2}$ average concentration normalized to internal standard in log scale, ${ }^{3} \mathrm{n} / \mathrm{a}=$ no data available for this compound from pathway databases, ${ }^{*}$ and ${ }^{\dagger}$ represent the two stereoisomers of these compounds.

Table 3: ANOVA analysis and comparison of 24 representative metabolites across culture time points.

The diauxic growth pattern, therefore, indicates the potential for the induced expression of an extra-cellular $\alpha$-amylase once glucose has been depleted.

PCR amplification of $16 \mathrm{~S}$ rDNA and genes encoding AMT, DOI, MYO, AMY, and TOPO.

Using available bioinformatics databases and previously published sequence information, six genes of interest were targeted for analysis coding for AMT, DOI, MYO, AMY, TOPO and $16 \mathrm{~S}$ genes. The designed primers were successful in amplifying fragments of the predicted size (Figure 6). The AMT (lane 2) and DOI (lane 3) products had bright single bands at approximately $260 \mathrm{bp}$ and $340 \mathrm{bp}$, respectively. There were multiple bands of MYO products (lane 4), whereas the predicted product of $\sim 437 \mathrm{bp}$ is distinguishable. Two bands of equal intensity were approximately $130 \mathrm{bp}$ and $600 \mathrm{bp}$ in size from the amplification using the primers designed for AMY (lane 5 ). The $16 \mathrm{~S}$ gene product was a single specific band at $1500 \mathrm{bp}$ (lane 6).

Some non-specific binding occurred for all designed primers. This was expected to occur as these primers were either generically-designed or were created for use with non S. tenjimariensis species-specific gene sequences. The sequence information was then used to design primers that could be more specific for the S. tenjimariensis genes of interest.

\section{Sequence analysis}

The sequences for AMT and DOI products matched their targeted enzymes of interest with the top three Blastp scores showing sequence similarity to AMT aminotransferase and DOI synthases from other Streptomyces and a related genus (Table 4). S. tenebrarius was the species with the most similar sequencing match for both AMT and DOI primers, noteworthy because the primers used in this work were initially designed by researchers looking at the same genes in S. tenebrarius [31] Both AMT and DOI have relatively low Blastn top alignment scores (48.1 and 52.0), thus showing that although the nucleic acid sequence of $S$. tenjimariensis is significantly different from the closest matching S. tenebrarius, it appears to still maintain the same protein function supported by Blastp scores of 84.0 and 89.4 .

The MYO amplification was the most non-specific, however, careful purification of the $\sim 437 \mathrm{bp}$ target allowed for good sequence recovery. The sequencing results provided high Blastn sequence similarity to three Streptomyces species with high alignment scores $(149,117$ and 50.1) and the top third results included a gene sequence for an 
Citation: Denery JR, Cooney MJ, Li QX (2011) Diauxic and Antimicrobial Growth Phases of Streptomyces Tenjimariensis: Metabolite Profiling and Gene Expression. J Bioengineer \& Biomedical Sci 1:101. doi:10.4172/2155-9538.1000101

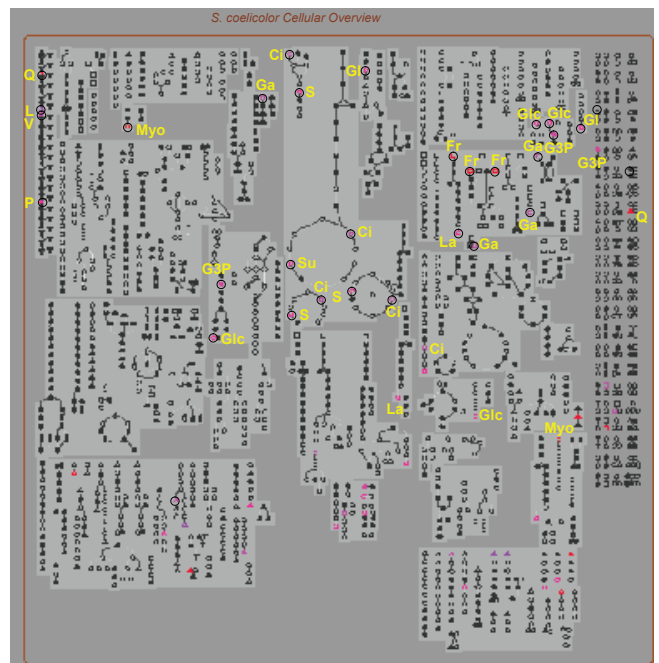

Figure 3: Cellular overview of 13 representative metabolites quantified from metabolite profiles at time point $36 \mathrm{~h}$. The remaining 11 representative metabolites from this study were not found in S. coelicolo A3(2) or S. avermitilis MA-4680 gene annotated data sets. Diagram obtained using the $S$. coelicolor A3(2) Pathway Tools Omics Viewer (http://biocyc.org). $\mathrm{Ci}=$ citrate, $\mathrm{Fr}=$ fructose, $\mathrm{Ga}=\beta$-D-galactose, $\mathrm{Glc}$ = glycerol, $\mathrm{G} 3 \mathrm{P}=$ glycerol-3-phosphate, $\mathrm{Q}=$ glutamine, $\mathrm{Gl}=$ glycolate, $\mathrm{La}=$ lactate, $\mathrm{L}=$ leucine, Myo $=$ myo-inositol, $\mathrm{P}=$ proline, $\mathrm{Su}=$ succinate, $\mathrm{V}=$ valine.

\section{a)}

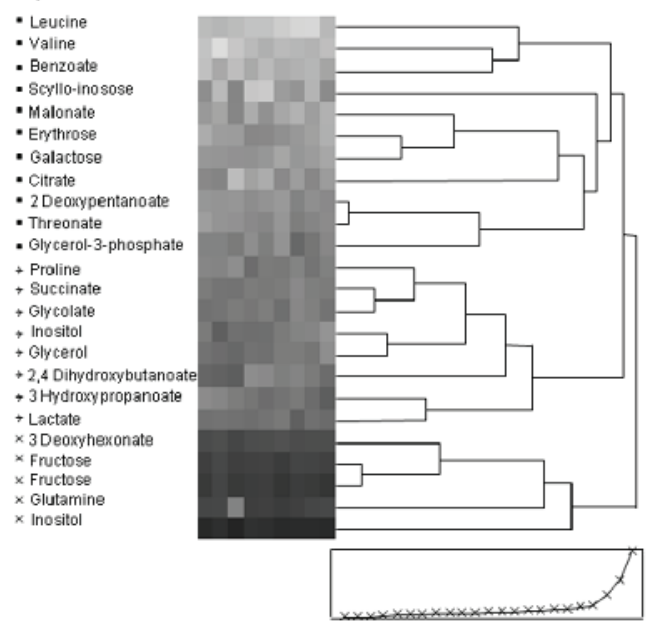

b)

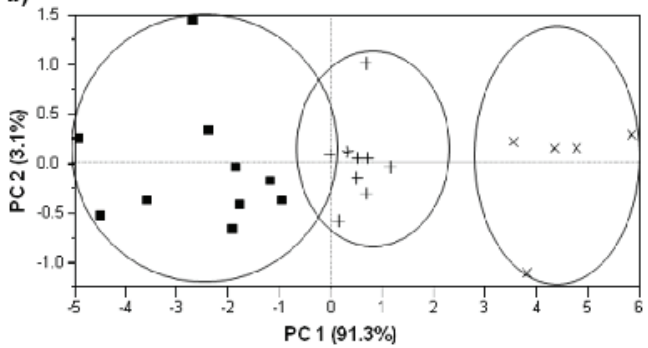

Figure 4: Multivariate analysis of 24 representative metabolites measured from the liquid culture of $S$. tenjimariensis sorted by metabolite grouping based on profile similarity. Normalized data of metabolite profiles for 3 replicate samples were arranged and visualized using a) HCA and b) PCA a)

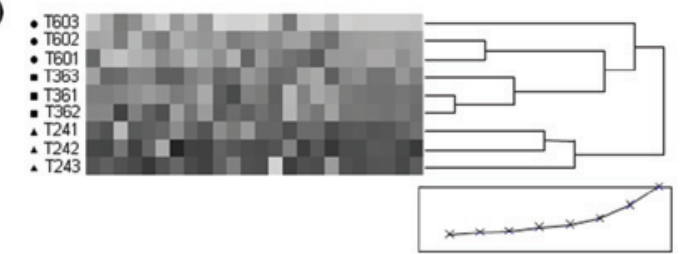

b)

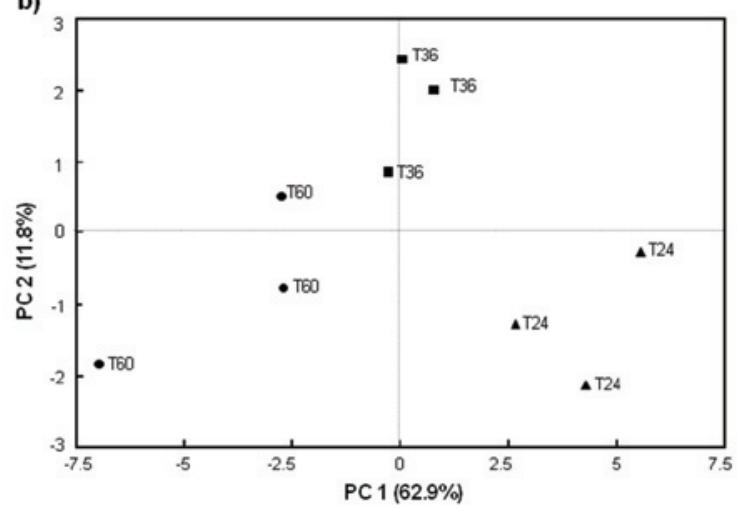

Figure 5: Multivariate analysis of 24 representative metabolites measured from the liquid culture of $S$. tenjimariensis sorted by time points. Normalized data of metabolite profiles for 3 replicate samples were arranged and visualized using a) HCA and b) PCA. In Figure 5a, T603, for example, stands for the $6 \mathrm{~h}$ sample replicate- 3 while T363 stands for the $36 \mathrm{~h}$ sample replicate- 3 . In Figure 5b, T36, for example, stands for the $36 \mathrm{~h}$ sample.

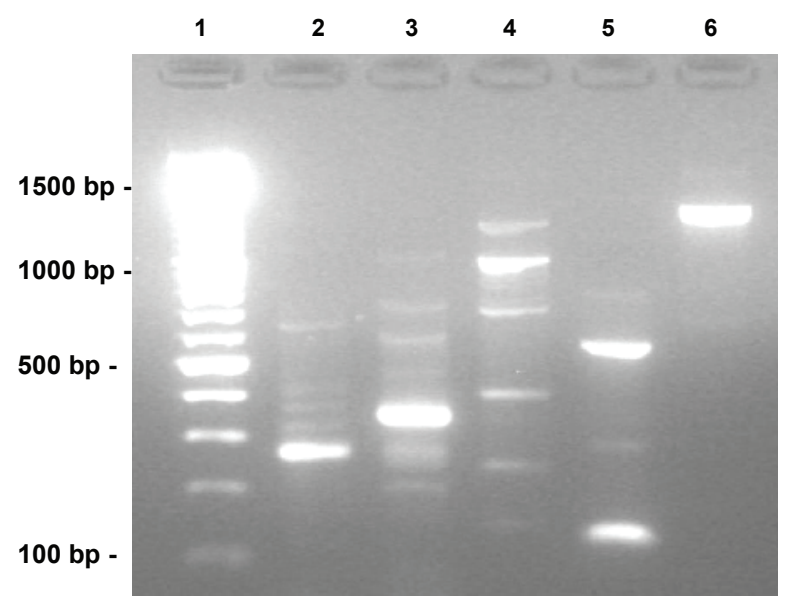

Figure 6: PCR amplification of S. tenjimariensis DNA. Lanes: 1, $100 \mathrm{bp}$ DNA ladder; 2, AMT 260 bp; 3, DOI 340 bp; 4, MYO 437 bp; 5, AMY 130 bp; TOPO 600 bp; 6, 16S rDNA 1500 bp.

antibiotic producing biosynthetic gene cluster specifically. The Blastp similarity scores suggested a high correlation with two hypothetical proteins in S. coelicolor A3(2) and S. avermitilis MA-4680 (101 and 100 , respectively) and high similarity to an uncharacterized conserved protein in Thermobifida fusca.

The AMY primers were relatively non specific, amplifying two distinct bands. The smaller band $~ 130$ bp provided high sequence similarity $(103,103,76.0)$ to AMY genes in three Streptomyces species, but yielded no match hits to target proteins. This could be due to the possibility that this particular part of the sequence is not a part of a 
Citation: Denery JR, Cooney MJ, Li QX (2011) Diauxic and Antimicrobial Growth Phases of Streptomyces Tenjimariensis: Metabolite Profiling and Gene Expression. J Bioengineer \& Biomedical Sci 1:101. doi:10.4172/2155-9538.1000101

Page 8 of 11

\begin{tabular}{|c|c|c|c|c|c|c|c|}
\hline Target Genes & Size (bp) & Blastn & Bit score & E value & Blastp & Bit Score & E value \\
\hline \multirow[t]{3}{*}{ AMT } & 245 & $\begin{array}{l}\text { Rhodopseudomonas palustris complete } \\
\text { genome; segment } 11 / 16\end{array}$ & 48.1 & 0.010 & $\begin{array}{l}\text { Streptomyces tenebrarius putative 2-deoxy- } \\
\text { scyllo-inosose aminotransferase }\end{array}$ & 84 & $1 \mathrm{E}-15$ \\
\hline & & $\begin{array}{l}\text { S. tenebrarius tobramycin biosynthetic gene } \\
\text { cluster }\end{array}$ & 46.1 & 0.038 & $\begin{array}{l}\text { Streptomyces fradiae L-glutamine:2-deoxy- } \\
\text { scyllo-inosose aminotransferase }\end{array}$ & 83.2 & $2 \mathrm{E}-15$ \\
\hline & & $\begin{array}{l}\text { Chromobacterium violaceum section } 4 \text { of } 16 \text { of } \\
\text { the complete genome }\end{array}$ & 44.1 & 0.15 & $\begin{array}{l}\text { Streptomyces ribosidificus L-glutamine:2- } \\
\text { deoxy-scyllo-inosose aminotransferase }\end{array}$ & 80.9 & $9 \mathrm{E}-15$ \\
\hline \multirow[t]{3}{*}{ DOI } & 300 & $\begin{array}{l}\text { Streptomyces coelicolor A3(2) complete } \\
\text { genome; segment } 12 / 29\end{array}$ & 52.0 & 8.0E-04 & $\begin{array}{l}\text { S. tenebrarius 2-deoxy-scyllo-inosose } \\
\text { synthase }\end{array}$ & 89.4 & $3.0 \mathrm{E}-17$ \\
\hline & & $\begin{array}{l}\text { S. tenebrarius tobramycin biosynthetic gene } \\
\text { cluster }\end{array}$ & 50.1 & $3.0 \mathrm{E}-03$ & $\begin{array}{l}\text { Micromonospora echinospora 2-deoxy-scyllo- } \\
\text { inosose synthase }\end{array}$ & 83.2 & $2.0 \mathrm{E}-15$ \\
\hline & & $\begin{array}{l}\text { Symbiobacterium thermophilum complete } \\
\text { genome }\end{array}$ & 48.1 & $1.2 \mathrm{E}-02$ & $\begin{array}{l}\text { Streptomyces kanamyceticus 2-deoxy-scyllo- } \\
\text { inosose synthase }\end{array}$ & 79.3 & $3.0 \mathrm{E}-14$ \\
\hline \multirow[t]{3}{*}{ MYO } & 341 & $\begin{array}{l}\text { S. coelicolor A3(2) complete genome; segment } \\
12 / 29\end{array}$ & 149 & $5 E-33$ & $\begin{array}{l}\text { S. coelicolor A3(2) conserved hypothetical } \\
\text { protein }\end{array}$ & 101 & $6 \mathrm{E}-21$ \\
\hline & & $\begin{array}{l}\text { Streptomyces avermitilis MA-4680 genomic } \\
\text { DNA, complete genome }\end{array}$ & 117 & $2 \mathrm{E}-23$ & S. avermitilis MA-4680 hypothetical protein & 100 & $1 \mathrm{E}-20$ \\
\hline & & $\begin{array}{l}\text { Streptomyces noursei nystatin biosynthetic } \\
\text { gene cluster }\end{array}$ & 50.1 & 0.004 & $\begin{array}{l}\text { Thermobifida fusca uncharacterized con- } \\
\text { served protein }\end{array}$ & 131 & $5 \mathrm{E}-07$ \\
\hline \multirow[t]{3}{*}{ AMY } & 130 & Streptomyces griseus alpha-amylase gene & 103 & $8 \mathrm{E}-20$ & - & - & - \\
\hline & & $\begin{array}{l}\text { Streptomyces limosus alpha-amylase gene, } \\
\text { complete cds }\end{array}$ & 103 & $8 \mathrm{E}-20$ & - & - & - \\
\hline & & Streptomyces lividans aml gene & 76 & $2 \mathrm{E}-11$ & - & - & - \\
\hline $\begin{array}{l}\text { Reference } \\
\text { Genes }\end{array}$ & Size (bp) & Blastn & Bit score & E value & Blastp & Bit Score & E value \\
\hline \multirow[t]{3}{*}{ TOPO } & 539 & $\begin{array}{l}\text { S. avermitilis MA- } 4680 \text { genomic DNA, com- } \\
\text { plete genome }\end{array}$ & 617 & $\mathrm{E}-173$ & $\begin{array}{l}\text { S. avermitilis MA- } 4680 \text { putative DNA topoi- } \\
\text { somerase I }\end{array}$ & 282 & $2 \mathrm{E}-75$ \\
\hline & & $\begin{array}{l}\text { S. coelicolor A3(2) complete genome; segment } \\
13 / 29\end{array}$ & 523 & $\mathrm{E}-145$ & $\begin{array}{l}\text { S. coelicolor A3(2) probable DNA topoisom- } \\
\text { erase I }\end{array}$ & 275 & $4 \mathrm{E}-73$ \\
\hline & & $\begin{array}{l}\text { Nocardia farcinica IFM } 10152 \text { DNA, complete } \\
\text { genome }\end{array}$ & 133 & $5 \mathrm{E}-28$ & Topoisomerase IA Thermobifida fusca & 213 & $1 \mathrm{E}-54$ \\
\hline \multirow[t]{3}{*}{$16 S$} & 480 & $\begin{array}{l}\text { Streptomyces sp. LS-A24 16S ribosomal RNA } \\
\text { gene, partial sequence }\end{array}$ & 735 & $0 \mathrm{E}+00$ & - & - & - \\
\hline & & $\begin{array}{l}\text { Streptomyces somaliensis M29, 16S rRNA } \\
\text { gene }\end{array}$ & 728 & $0 \mathrm{E}+00$ & - & - & - \\
\hline & & S. somaliensis DSM 40738, 16S rRNA gene & 720 & $0 \mathrm{E}+00$ & - & - & - \\
\hline
\end{tabular}

Table 4: Results of BLAST sequence analysis for target and reference genes.

protein coding sequence or that the query sequence was too small $(\sim$ 43 residues) to provide specific protein data. The larger band sequence had a very high correlation to two Streptomyces and one Nocardia species (Blastn 617, 523, 133; Blastp 282, 275, 213) and encoded the DNA topoisomerase I (TOPO) that acts as part of a cell's replicative machinery in removing DNA supercoils. This necessary functionality of TOPO in cell replication could make it a good candidate for use as a housekeeping or reference gene and would be investigated in further gene expression analysis experiments.

The 16S rDNA was amplified with the forward primer. The $480 \mathrm{bp}$ product was an almost perfect match with that of Streptomyces sp. LSA24 and two strains of $S$. somaliensis having Blastn scores of 735, 728 and 720 , respectively, with the lowest $\mathrm{E}$ value score possible of $0 \mathrm{E}+00$. Since $16 \mathrm{~S}$ rDNA is not expressed as a protein, there was no Blastp score.

\section{PCR and RT-PCR using $S$. tenjimariensis specific primers}

Once sequence similarity was established, new primers were designed based on the resulting sequences. Through the use of these $S$. tenjimariensis specific primers in RT-PCR experiments of RNA isolated at all time points, gene expression was observed for the target genes AMT, DOI, MYO, and AMY, and for the reference genes TOPO and 16S, (Figure $7 \mathrm{a}, \mathrm{b}, \mathrm{c}, \mathrm{d}, \mathrm{e}, \mathrm{f}$, lanes 2-5). The results suggest that the putative aminoglycoside biosynthetic enzymes AMT, DOI, MYO and AMY are expressed throughout $S$. tenjimariensis growth. Although RT-PCR can be used to indicate expression, it cannot be used to describe how the levels of gene expression differ from sample to sample for a single gene of interest.

Comparison with control reactions in which the reverse transcriptase step was omitted and in which no template was provided shows the purity of the RNA used in the experiment as well as the purity of the gene-specific primers (lanes 6 and 7, respectively). Additionally, each primer pair was used for the amplification of cDNA synthesized from the RNA stock at each time-point. Amplified bands (lane 8) represent PCR amplification of synthesized cDNA representing all four time-points.The fact that all six genes display an amplified product indicates that cDNA synthesis was comprehensive and that it could be used for further measurement of gene expression.

\section{qPCR analysis}

The expression of three target genes AMT, MYO and AMY was compared to that of the reference genes TOPO and $16 \mathrm{~S}$ across each of the four time-points. The time $10 \mathrm{~h}$ sample was used as a control and compared against the time $24 \mathrm{~h}, 36 \mathrm{~h}$ and $60 \mathrm{~h}$ samples. To accurately compare the changes in expression of the target genes, their quantities must be measured relative to changes in the reference genes. The fold changes in expression for the TOPO gene were less consistent than those for the $16 \mathrm{~S}$ gene. The fold changes of the TOPO gene ranged from 3.10 (time $10 \mathrm{~h} v s .24 \mathrm{~h}$ ) to 1.09 (time $10 \mathrm{~h} v s .60 \mathrm{~h}$ ) with no fluorescent signal detected at time $36 \mathrm{~h}$ (data not shown). The $16 \mathrm{~S}$ gene expression varied little from 1.73-fold (time 10 vs. 24) to 1.12-fold (time $10 \mathrm{~h} v s$. 
$36 \mathrm{~h}$ ) and 1.19 -fold (time $10 \mathrm{~h} v s .60 \mathrm{~h}$ ) (data not shown). Due to this discrepancy between the variability of TOPO and $16 \mathrm{~S}$, the suitability of $\mathrm{TOPO}$ as a reference gene requires further qPCR experiments. In the remainder of the present study, $16 \mathrm{~S}$ was used as a reference gene.

Figure 8 shows an initial decrease in expression of AMT at time 24 $\mathrm{h}$ followed by a slow increase in expression by time $36 \mathrm{~h}$ and then time $60 \mathrm{~h}$. This change in expression is consistent when compared to the reference $16 \mathrm{~S}$ gene displaying a 0.32 fold decrease in expression (time $10 \mathrm{~h} v s .24 \mathrm{~h}$ ), then approximately the same expression 1.0 (time $10 \mathrm{~h}$ $v s .36 \mathrm{~h}$ ), followed by a 2.7 fold increase (time $10 \mathrm{~h} v s .60 \mathrm{~h}$ ). The MYO gene had even less variability than the AMT gene with ratios of 0.06 , 0.05 , and 0.16 (time $10 \mathrm{~h} v s .24 \mathrm{~h}, 36 \mathrm{~h}$, and $60 \mathrm{~h}$, respectively) when compared with the $16 \mathrm{~S}$ reference gene at all time-points. The AMY gene, as well, gave very consistent expression with ratios of $0.61,0.53$, 0.73 (time $10 \mathrm{~h}$ vs. $24 \mathrm{~h}, 36 \mathrm{~h}$ and $60 \mathrm{~h}$, respectively) relative to the $16 \mathrm{~S}$ reference gene at all time-points.

While still preliminary, the $\mathrm{qPCR}$ experimental data provided a quantitative measurement of the gene expression across time-points. In this survey analysis the AMT gene proved to have greater expression changes than the other target genes tested. The ratios, however, are still quite small in comparison with what would be an expected measure of significant expression change. More data points will need to be added to the standard curve as well as more replicate numbers for standards and samples, in order to provide more stable measures of efficiency ( 90 $100 \%$ ) for use in further expression calculations.

Metabolite profiling was applied to the relatively uncharacterized bacterium $S$. tenjimariensis. On-line monitoring of acid and base consumption, antimicrobial activity and HPLC analysis of the culture supernatant were used to identify the diauxic and antimicrobial production phases of growth for the batch bioreactor culture of $S$. tenjimariensis. Extraction and TMS derivatization of polar fractions from the bioreactor culture allowed for the GC separation and MS

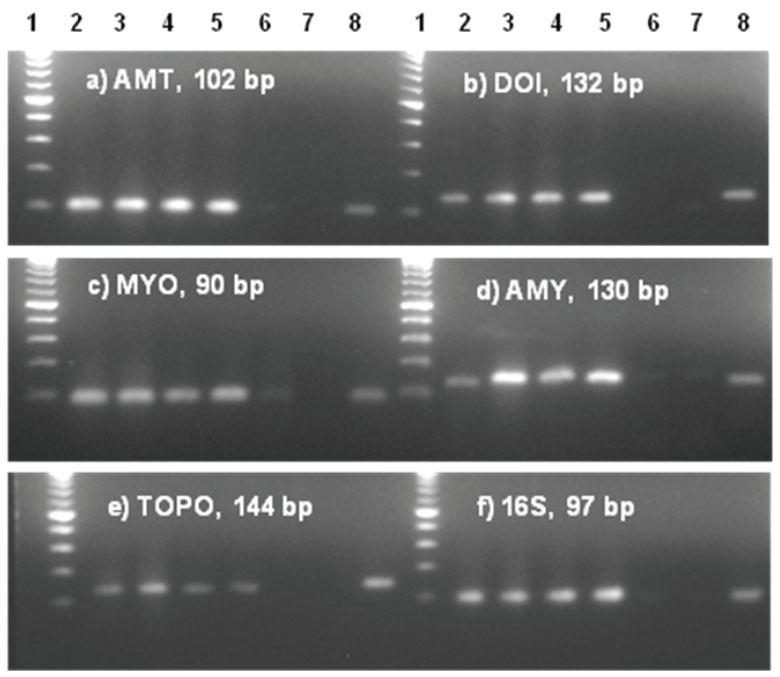

Figure 7: RT-PCR amplification of $S$. tenjimariensis RNA and cDNA using species-specific primers. a) AMT 102 bp, b) DOI 132 bp, c)MYO 90 bp, d) AMY 130 bp e)TOPO 144 bp, f)16S 97 bp Lanes: 1, 100 bp DNA ladder; 2, RT-PCR 10 h RNA; 3, RT-PCR 24 h RNA 4, RT-PCR 36 h; 5 , RT-PCR 60 h RNA; 6 , + control reaction RNA as template no reverse transcriptase; 7 , - control reaction with no nucleotide template, 8, cDNA as template. analysis of nearly 200 peaks. Metabolite profiles differed qualitatively and quantitatively among the growth phases. Changes in the metabolite values were computed with ANOVA analysis showing variable statistical significance in concentration change across time points. Evidence of a significant decrease in sugar concentration over time is of particular interest in relation to the antimicrobial production growth phase of the bioreactor culture. The aminoglycoside antibiotic istamycin attributed to antimicrobial activity in S. tenjimariensis is a di-pseudosaccharide containing two carbohydrate rings [22]. Other bacteria that produce aminoglycosides of the same family as $S$. tenjimariensis produced istamycin - the fortimicin family - contain biosynthetic pathways that use inositol (myo- and scyllo- forms) and other sugars as precursors [41]. As there is a constant decline in sugars within the cell throughout the bioreactor run, it is possible that this may be indicative of the metabolic shift in the bacteria to produce the antimicrobials measured in the agar diffusion assays. While interesting, establishing a connection between declining sugar levels particularly that of inositol and the inverse trend of increased istamycin production demands further study.

In this study, by examining metabolic changes and using available gene sequence and function data from bioinformatic resources, genes related to several aspects of metabolism in S. tenjimariensis were identified. With little genetic information available regarding $S$. tenjimariensis (only one gene has been characterized thus far), we were able to design gene-specific primers as a means of identifying enzymes potentially involved in secondary metabolism in $S$. tenjimariensis L-glutamine aminotransferase (AMT), 2-deoxy-scyllo-inosose synthase (DOI), myo-inositol dehydrogenase (MYO) and $\alpha$-amylase (AMY). Their specific primers were designed and used for the analysis of mRNA expression through RT-PCR. It was found that $S$. tenjimariensis

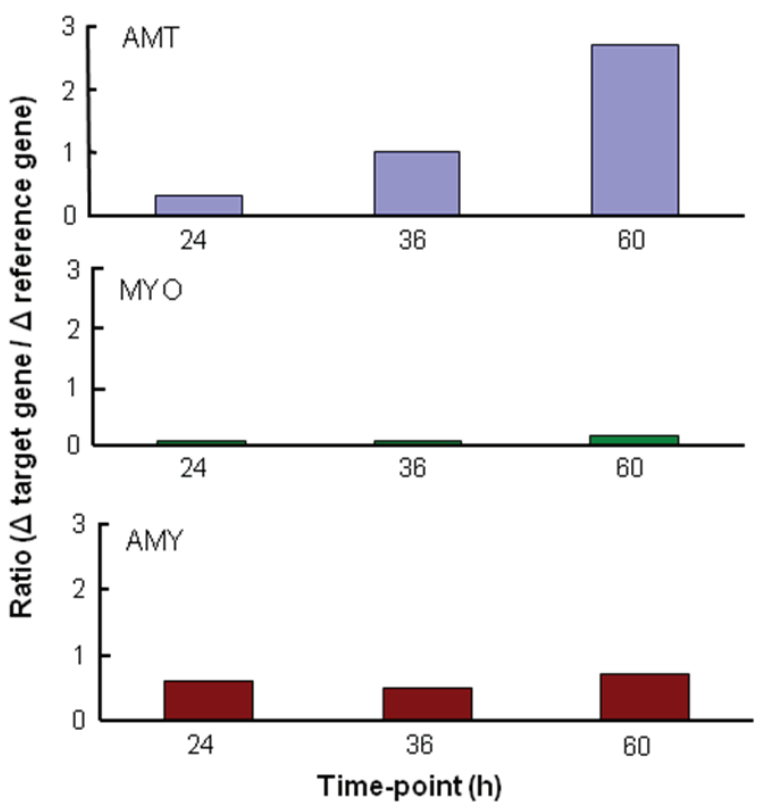

Figure 8: Preliminary qPCR results for AMT, MYO, and AMY genes. Calculations based upon Pfaffl formula [30]. The time $10 \mathrm{~h}$ sample was used as a control and compared against the time $24 \mathrm{~h}, 36 \mathrm{~h}$ and $60 \mathrm{~h}$ samples. $16 \mathrm{~S}$ was the reference gene. Data represents one replicate of each sample and three data point standard curves. AMT standard curve correlation coefficient $(\mathrm{cc})=0.999$, PCR efficiency $=97.2 \%$; MYO $(\mathrm{cc})=1.000$, PCR efficiency = $64.0 \%$; $\mathrm{AMY}(\mathrm{cc})=0.956, \mathrm{PCR}$ efficiency $=125.8 \% ; 16 \mathrm{~S}$ coefficient $(\mathrm{cc})=$ 1.000, PCR efficiency $=97.2 \%$. 
expressed all four of the genes of interest during three different phases of growth. Preliminary qPCR results indicate that AMT, MYO and AMY genes are appropriate to monitor their expression levels in relevance to the substrate utilization and istamycin biosynthesis during bioreactor growth. Conclusions regarding their expression in relation to the substrate utilization and istamycin production, however, cannot be definitively determined from the present study.

This work exemplifies how metabolic data can be used to identify pathways and enzymes of interest as a means of characterizing little known organisms. In addition to sequence data, expression data of specific genes were obtained. Knowing whether or not these particular genes are being expressed at specific time intervals in relation to changes in metabolism helps our understanding of the genetic regulation of $S$. tenjimariensis in response to environmental factors.

It is consistent with the known dynamism of metabolic networks. Such metabolite groupings can, however, be used to visualize potential patterns in the behavior of metabolite groups relative to culture time and could serve as a basis for the determination of the function of un-identified metabolites. Additionally PCA and HCA analysis helps to picture the uniqueness of the profiles between time points and the utility of metabolite profiling in distinguishing growth phases.

In summary, this study demonstrates the utility of metabolite profiling in the study of microbial metabolism specifically as a jumping off point for further metabolic, proteomic or genetic analysis. While most metabolomic analyses thus far have focused on subjects considered as model organisms, this study shows the adoption of metabolite profiling technologies to the study of a relatively uncharacterized model. Pathogenic microorganisms and their associated host response are a good example of such uncharacterized models for which metabolite profiling technologies hold great promise. This study shows metabolite profiles that are unique to growth phase and exemplifies how they can be used for further applications in the understanding of microbial metabolism and physiology. Such an analysis can be extended to similar clinical challenges as monitoring changes in growth of microbial pathogens or to distinguishing temporal changes in patient response to infection or novel therapeutics.

\section{Acknowledgments}

We thank C. Cannizzaro, N. Rathfelder, V. Magoña, G. Steward, J. Stroncek, S. Campbell, and R. Harada for their useful discussion and technical support. The statistical software platforms were provided through NIH Grant number RR-16467 from the BRIN program of the National Center for Research Resources. This work was supported by the ERC Program of the National Science Foundation under Award Number EEC-9731725.

\section{References}

1. Mendes $P$ (2002) Emerging bioinformatics for the metabolome. Brief Bioinform 3: $134-145$.

2. O'Farrell PH (1975) High resolution two-dimensional electrophoresis of proteins. J Biol Chem 250: 4007-4021.

3. Aebersold R, Mann M (2003) Mass spectrometry-based proteomics. Nature 422: 198-207.

4. Victor E, Velculescu, Lin Zhang, Bert Vogelstein, Kenneth W Kinzler (1995) Serial analysis of gene expression. Science 270: 484-487.

5. Mark Schena, Dari Shalon, Ronald W Davis, Brown PO (1995) Quantitative monitoring of gene expression patterns with a complementary DNA microarray. Science 270: 467-70

6. Oliver SG (1996) From DNA sequence to biological function. Nature 379: 597-600

7. Hieter P, Boguski M (1997) Functional genomics: it's all how you read it. Science 278: 601-602.
8. Ideker T, Galitski T, Hood L (2001) A new approach to decoding life: systems biology. Annual review of genomics and human genetics 2: 343-372.

9. Kitano H (2000) Perspectives in Systems Biology. New Generation Computing 18: 199-216.

10. Sumner LW, Mendes P, Dixon RA (2003) Plant metabolomics: large-scale phytochemistry in the functional genomics era. Phytochemistry 62: 817-836.

11. Trethewey RN, Krotzky AJ, Willmitzer L (1999) Metabolic profiling: a Rosetta Stone for genomics?. Curr Opin Plant Biol 2: 83-85.

12. Fiehn O, Kopka J, Trethewey RN,Willmitzer L (2000) Identification of Uncommon Plant Metabolites Based on Calculation of Elemental Compositions Using Gas Chromatography and Quadrupole Mass Spectrometry. Anal Chem 72: 3573-3580.

13. Jeong ML, Jiang H, Chen HS, Tsai CJ, Harding SA (2004) Metabolic Profiling of the Sink-to Source Transition in Developing Leaves of Quaking Aspen. Plant Physiol 136: 3364-3375.

14. Desbrosses GG, Kopka J, Udvardi MK (2005) Lotus japonicus metabolic profiling. Development of gas chromatography-mass spectrometry resources for the study of plant-microbe interactions. Plant Physiol 137: 1302-18.

15. Fancy SA, Beckonert O, Darbon G, Yabsley W, Walley R, et al. (2006) Gas chromatography/flame ionisation detection mass spectrometry for the detection of endogenous urine metabolites for metabonomic studies and its use as a complementary tool to nuclear magnetic resonance spectroscopy. Rapid Commun Mass Spectrom 20: 2271-2280.

16. Kuhara T (2005) Gas chromatographic-mass spectrometric urinary metabolome analysis to study mutations of inborn errors of metabolism. Mass Spectrom Rev 24: 814-827.

17. Villas-Boas SG, Moxley JF, Akesson M, Stephanopoulos G, Nielsen J (2005) High-throughput metabolic state analysis: the missing link in integrated functional genomics of yeasts. Biochem J 388: 669-677.

18. Devantier R, Scheithauer B, Villas-Boas SG, pedersen S, Olsson L (2005) Metabolite profiling for analysis of yeast stress response during very high gravity ethanol fermentations. Biotechnol Bioeng 90: 703-14.

19. Koek MM, Muilwijk B, Vander werf MJ, Hankemeier T (2006) Microbia metabolomics with gas chromatography/mass spectrometry. Anal Chem 78: 3839.

20. Strelkov S, von Elstermann M, Schomburg D (2004) Comprehensive analysis of metabolites in Corynebacterium glutamicum by gas chromatography/mass spectrometry. Biol Chem 385: 853-861.

21. Okami Y, Hotta K, Yoshida M, Ikeda D, Kondo S, et al. (1979) New aminoglycoside antibiotics, istamycins A and B. J Antibiot 32: 964-966.

22. Hotta K, Saito N, Okami Y (1980) Studies on new aminoglycoside antibiotics istamycins, from an actinomycete isolated from a marine environment. I. The use of plasmid profiles in screening antibiotic-producing streptomycetes. $J$ Antibiot (Tokyo) 33: 1502-1509.

23. Slattery M, Rajbhandari I, Wesson K (2001) Competition-mediated antibiotic induction in the marine bacterium Streptomyces tenjimariensis. Microb Eco 41: 90-96.

24. Ohta T, Hasegawa M (1993) Analysis of the nucleotide sequence of fmrT encoding the self-defense gene of the istamycin producer, Streptomyces tenjimariensis ATCC 31602; comparison with the squences of kamB of Streptomyces tenebrarius NCIB 11028 and kamC of Saccharopolyspora hirsuta CL102. J Antibiot (Tokyo) 46: 511-517.

25. Rathfelder (2002) N Set-up of a model system for the study of secondary metabolite production and bioprocess intensification in Streptomyces tenjimariensis. Mannheim University of Applied Science, Mannheim, Germany.

26. Hotta K, Okami Y, Umezawa H (1980) Studies on new aminoglycoside antibiotics, istamycins, from an actinomycete isolated from a marine environment. II. Possible involvement of plasmid in istamycin production. J Antibiotics (Tokyo) 33: 1510-1514.

27. Buchholz A, Takors R, Wandrey C (2001) Quantification of intracellular metabolites in Escherichia coli K12 using liquid chromatographic-electrospray ionization tandem mass spectrometric techniques. Anal Biochem 295: 129-137

28. Buchholz A, Hurlebaus J, Wandrey C, Takors R (2002) Metabolomics: quantification of intracellular metabolite dynamics. Biomol Eng 19 : 5-15.

29. Faijes M, Mars AE, Smid EJ (2007) Comparison of quenching and extraction 
Citation: Denery JR, Cooney MJ, Li QX (2011) Diauxic and Antimicrobial Growth Phases of Streptomyces Tenjimariensis: Metabolite Profiling and Gene Expression. J Bioengineer \& Biomedical Sci 1:101. doi:10.4172/2155-9538.1000101

Page 11 of 11

methodologies for metabolome analysis of Lactobacillus plantarum. Microb Cell Fact 6: 27.

30. Schweer H (1982) Gas chromatography-mass spectrometry of aldoses as O-methoxime, O-2-methyl-2-propoxime and O-n-butoxime pertrifluoroacetyl derivatives on OV-225 with methylpropane as ionization agent: I. Pentoses. J Chromatogr A 236: 355-360.

31. Tam YY, Normanly J (1998) Determination of indole-3-pyruvic acid levels in Arabidopsis thaliana by gas chromatography-selected ion monitoring-mass spectrometry. J Chromatogr A 800: 101-108.

32. Kharel K, Basnet DB, Lee HC, Liou K, Woo JS, et al. (2004) Isolation and characterization of the Tobramycin Biosynthetic Gene Cluster from Streptomyces tenebrarius. FEMS Microbiol Letters 230: 185-190.

33. Lane DJ (1991) 16S/23S rRNA sequencing, In Stackenbrandt E and Goodfellow M (ed.) Nucleic acid techniques in bacterial systematics. John Wiley and Sons Ltd. Chichester, UK 115-175.

34. Winship PR (1989) An improved method for directly sequencing PCR amplified material using dimethyl sulphoxide. Nucleic Acids Research 17: 1266.
35. Pomp D, Medrano JF (1991) Organic solvents as facilitators of polymerase chain reaction. BioTechniques 10: 58-59.

36. Pfaffl MW (2001) A New Mathematical Model for Relative Quantitation in RealTime RT-PCR. Nucleic Acids Research 29: 2002-2007.

37. Kanehisa M, Goto S (2000) KEGG: Kyoto Encyclopedia of Genes and Genomes. Nucleic Acids Research 28: 27-30.

38. Caspi R, Foerster H, Fulcher CA, Hopkinson R, Ingraham J, et al. (2004) MetaCyc: a multiorganism database of metabolic pathways and enzymes. Nucleic Acids Research 32: D438-442.

39. Karp PD, Paley S, Romero P (2002) The pathway tools software. Bioinformatics 18: S225-232.

40. Fiehn O, Kopka J, Dormann P, Thomas Altmann, Richard N.Trethewey, et al (2000) Metabolite profiling for plant functional genomics. Nature Biotechnology 18: 1157-1161.

41. Dairi T, Hasegawa M (1989) Common biosynthetic feature of fortimicin-group antibiotics. J Antibiotics 42: 934-943. 